I Amino N, Miyai K, Onishi T, Hashimoto T, Arai K, Ishibashi K, et el. Transient hypothyroidism after delivery in autoimmune thyroiditis. f Clin Endocrinol Metab 1976;42:296-301.

2 Amino N, Mori $\mathrm{H}$, Iwatani $\mathrm{Y}$, Tanizawa $\mathrm{O}$, Kawashima $M$, Tsuge I, et al. High prevalence of transient postpartum thyrotoxicosis and hypothyroidism. New Engl F Med 1982;306:849-52.

3 Jansson R, Bernander S, Karlsson A, Levin K, Nilson G. Autoimmune thyroid dysfunction in the post partum period. $\mathcal{F}$ Clin Endocrinol Metab 1984;58:681-7.

4 Fung HYM, Kologlu M, Collison K, John R, Richards CJ, Hall R. Postpartum thyroid dysfunction in Mid-Glamorgan. BMf 1988;296:241-4.

5 Hayslip CC, Fein HG, O'Donnell VM, Friedman DS, Klein TA, Smallridge $\mathrm{RC}$. The value of serum antimicrosomal antibody testing in screening for symptomatic post partum thyroid dysfunction. Am $\mathcal{J}$ Obstet Gynecol 1988;159:203-9.

6 Amino $\mathrm{N}$, Miyai $\mathrm{K}$. Post partum autoimmune endocrine syndromes. In: Autonmmune endocrine disease. New York: John Wiley, 1983:247.

7 Thomas FB, Mazzaferri EL, Skillman TG. Apathetic thyrotoxicosis: a distinctive clinical and laboratory entity. Ann Intern Med 1970;72:679-85.

8 Van Uitert RL, Russakoff LM. Hyperthyroid chorea mimicking psychiatric disease. Am J Psychiatry 1979;136:1208-10.

9 Folks DG. Organic affective disorder and underlying thyrotoxicosis. Psychosomatics 1984;25:243-9.

10 Nemeroff CN, Simon JS, Haggerty JJ, Evans DL. Antithyroid antibodies in depressed patients. Am $\mathcal{F}$ Psychiatry 1985;142:840-3.

1 Kumar R, Robson KM. A prospective study of emotional disorders in childbearing women. $\mathrm{Br} \mathcal{f}$ Psychiatry 1984;144:35-47.

12 Paykel ES, Emms EM, Fletcher J, Rassaby ES. Life events and social support in puerperal depression. $B r f$ Psychiatry 1980;136:339-46.

13 Watson JP, Elliott SA, Rugg AJ, Brough DI. Psychiatric disorder in pregnancy and the first postnatal year. Brf Psychiarry 1984:144:453-62.

4 Cox JL, Connor Y, Kendell RE. Prospective study of the psychiatric disorders of childbirth. Br f Psychiatry 1982;140:111-7.

15 Harris B, Johns S, Fung H, Thomas R, Walker R, Read G, et al. The hormon environment of post natal depression. Br f Psychiatry 1989;154:660-7.

16 Harris B, Fung H, Johns S, Kologlu M, Bhatti R, McGregor AM, et al. Transient post partum thyroid dysfunction and post natal depression. f Affective Disord 1989;17:243-9.

17 Goldman JM. Post partum thyroid dysfunction. Arch Intern Med 1986;146: 1296-9.

18 Jansson R, Dahlberg PA, Winsa B, Meirik O, Safwenberg J, Karlsson A. The post partum period constitutes an important risk for the development of clinical Graves disease in young women. Acta Endocrinologica 1987;116: 321-5.

9 Goldberg DP. The detection of psychiatric illness by questionnaire. Oxford: Oxford University Press, 1972. (Maudsley monographs 21.)

20 Nott PN. Psychiatric illness following childbirth in Southampton: a case register study. Psychol Med 1982;12:557-61.

21 Spitzer RL, Endicott J, Robins E. Research diagnostic criteria: rationale and reliability. Arch Gen Psychiatry 1978;36:773-82.
22 Hamilton $M$. Development of a rating scale for primary depressive illness. Br 7 Soc Clin Psychol 1962:66:278-96.

23 Paykel ES, Prusoff BA, Uhlenhuth EH. Scaling of life events. Arch Gen Psychiatry 1971;25:340-7.

$24 \operatorname{Cox}$ JL, Holden JM, Sagovsky R. Detection of postnatal depression: development of the 10-item Edinburgh postnatal depression scale. Br F Psychiatry 1987;150:782-6.

25 Zigmund AS, Snaith RP. The hospital anxiety and depression scale. Acta Psychiatrica Scand 1983;67:361-70.

26 John R, Jones MK. An immunoradiometric assay for human thyrotropin. Clin Chem 1984;30:1396-8.

27 Groves CJ, Howells RD, Williams S, Darke C, Parkes AB. Primary standardisation for the ELISA of serum thyroperoxidase and thyroglobuli antibodies and their prevalence in a normal Welsh population. f Clin Lab Immunol 1990;32:147-51.

28 Dantzer R, Kelley $\mathrm{KW}$. Stress and immunity: an integrated view of relationships between the brain and the immune system. Life Sciences 1989;44:1995-2008.

29 Stein M, Miller AH, Trestman RL. Depression, the immune system, and health and illness. Arch Gen Psychiatry 1991:48:171-8.

30 Stewart DE, Addison AM, Robinson GE, Joffe R, Burrow GN, Olmsted MP. Thyroid function in psychosis following childbirth. Am $\mathcal{f}$ Psychiatry 1988; 145:1579-81

31 Scott EM, McGarrigle HHG, Lachelin GCL. The increase in plasma and saliv cortisol levels in pregnancy is not due to increase in corticosteroid bindin globulin levels. f Clin Endocrinol Metab 1990;71:639-44.

32 Prentice LM, Phillips DIW, Sarsero D, Beever K, McLachlan SM, Smith BR. Geographical distribution of subclinical thyroid disease in Britain: a study using highly sensitive direct assays for autoantibodies to thyroglobulin and thyroid peroxidase. Acta Endocrinologica 1990;123:493-8.

33 Young LD. Organic affective disorder associated with thyrotoxicosis. Psychosomatics 1984;25:490-2.

34 Mckenzie TB, Popkin MK. Organic anxiety syndrome. Am f Psychiatry $1983 ; 140: 342-4$

35 Lipowski ZJ. A new look at organic brain syndrome. Am $\mathcal{f}$ Psychiatry $1980 ; 137: 674-8$

36 American Psychiatric Association. Diagnostic and statistical manual of mental disorders (DSM III R). 3rd ed. Washington, DC: APA, 1987.

37 Pitt B. Depression following childbirth. Hospital Update 1991;17:133-40.

38 Cooper PJ, Campbell EA, Day A, Kennerley H, Bond A. Non-psychotic psychiatric disorder after childbirth: a prospective study of prevalence, incidence, course and nature. Brf Psychiatry 1988;152:799-806.

39 Kathol RG, Turner R, Delahunt J. Depression and anxiety associated with hyperthyroidism: response to antithyroid therapy. Psychosomatics 1986;27 501-5.

40 Lazarus JH, Othman S, Hall R, Richards CJ. Hypothyroidism. Lance 1990;336:315.

(Accepted 19 May 1992)

\title{
Contamination of skin and clothing of accident and emergency personnel
}

\author{
Patricia Littlechild, Alasdair Macmillan, \\ Maggie M White, David J Steedman
}

Department of Accident and Emergency Medicine, Royal Infirmary of Edinburgh, Edinburgh EH3 9YW

Patricia Littlechild, senior house officer

Alasdair Macmillan, senior house officer

Maggie M White, senior sister David J Steedman, consultant

Correspondence to: Dr Steedman.

BMF 1992;305:156-7
There is a striking contrast between clothing worn by medical staff working in resuscitation rooms of British accident and emergency departments - traditionally white coats over personal clothing - and the theatrestyle suits and gowns worn by resuscitation teams in North American centres. ${ }^{1}$ We do not know how often personal clothing or uniforms worn by accident and emergency personnel are spattered by blood and other body fluids and the protection afforded. There is, however, a definite risk of infection with various transmissible agents during patient contact. A case report of HIV infection in an accident and emergency health care worker after skin contamination with blood from a seropositive patient having cardiopulmonary resuscitation emphasised the need for suitable protective clothing. ${ }^{2}$ We attempted to assess the risk of clothing soilure and skin contamination during the daily work of accident and emergency staff in a busy teaching hospital accident and emergency department.

\section{Methods and results}

During 1-30 November 1991, 7402 patient attendances were recorded. Medical and nursing staff were asked to check their clothing and exposed skin after each patient contact and if there was definite soilure to clothing to check for visible evidence of underlying skin contamination. Two hundred forms were completed on 212 splash incidents.

Although $2 \cdot 2 \%$ of patients $(n=169)$ presenting to the department were treated within the resuscitation room, $36.3 \%$ of splash incidents (77) occurred there. Altogether $16.5 \%$ of splashes (35) occurred in the examination room mainly as a result of wound management $(22.6 \%$ of splashes (48)). A total of $28 \cdot 8 \%$ of splashes $(61)$ occurred during venous or arterial puncture, but contamination was recorded during 20 other procedures ranging from undressing the patient to last offices Some $47 \cdot 6 \%$ of splashes (101) resulted in skin contamination, and $28.7 \%$ of these (29) occurred despite the area being covered by personal clothing or a uniform. Personal clothing was soiled in $41.0 \%$ of incidents (87) and uniforms in $62.3 \%$ (132). A total of $71 \cdot 2 \%$ of splashes (151) were with patients' blood though splashes of vomitus, sputum, saliva, pus, faeces, and urine were documented.

\section{Comment}

The accident and emergency department operates a policy of "universal precautions," ${ }^{3}$ and medical and nursing staff receive guidance in appropriate barrier procedures when contact with blood or other body fluids is anticipated. Despite the appropriate use of gloves, masks, face shields, gowns, and plastic aprons splashes on clothing and skin contamination may occur. Nursing uniforms do not protect the legs or arms, and white coats do not protect against spattering of personal clothing. White coats have been shown to be a potential source of cross infection, especially when worn in accident and emergency departments. ${ }^{4}$ The soilure of personal clothing is both unacceptable and unhygienic. Contamination of skin despite wearing a 
uniform suggests that the design and material used are inappropriate.

In most accident and emergency departments the core of resuscitation teams is drawn from the staff working within the unit, and by the very nature of the emergency presentation there is often very little time to protect personal clothing and exposed skin. Not only are invasive procedures carried out in the resuscitation room but wound management elsewhere in the department results in appreciable risk of contamination. Nevertheless, it is impossible to anticipate all potential incidents, and staff are often unaware of contamination when it occurs.

An NHS report on the choice of reusable fabrics for operating theatres places emphasis on certain performance specifications which should meet British Standards. ${ }^{5}$ Synthetic fabrics of polyester, for example, are now available which meet these criteria. Protective clothing produced from such fabric acts as an efficient bacterial barrier and is liquid repellent. We are currently exploring the feasibility of providing our

\section{General practice and accident and emergency department care: does the patient know best?}

\section{Jonathan S Nguyen-Van-Tam, Daryll M Baker}

\section{Department of Accident and Emergency, University Hospital, Nottingham NG7 2UH \\ Jonathan S Nguyen-Van- \\ Tam, senior house officer \\ Daryll M Baker, senior house officer}

Correspondence to:

Dr J S Van-Tam,

Department of Public

Health Medicine and

Epidemiology, University

Hospital, Nottingham

NG7 2UH.

BMF 1992;305:157-8 medical and nursing staff with theatre-style uniforms made from this material.

This study highlights the inappropriate practice of wearing personal clothing in the accident and emergency department and the inadequate protection provided by traditional "uniforms." We recommend that accident and emergency staff should be protected by clothing of appropriate design and fabric.

We thank Mrs E MacDonald for help in preparing the manuscript.

I Skinner D, Driscoll P, Earlam R, eds. $A B C$ of major trauma. London: British Medical Journal, 1991

2 Centers for Disease Control. Update: human immunodeficiency virus infection in health care workers exposed to blood of infected patients. $M M W R$ 1987;36:285-8.

3 Centers for Disease Control. Recommendations for prevention of HIV transmission in health care settings. $M M W R$ 1987;36(suppl 2S):5-6S.

4 Wong D, Nye K, Hollis P. Microbial flora on doctors' white coats. BM 1991;303:1602-4

5 NHS Procurement Directorate. Choice of reusable fabrics for operating theatres. London: Department of Health, 1989. (NHS report STD/89/50.)

(Accepted 27 March 1992)
Accident and emergency departments function under a considerable workload. In a recent study, $12 \%$ of attendances were considered inappropriate (B Farrell et al, 35th meeting of Society for Social Medicine, 1991). Other work has shown that $8 \%$ of attenders have already consulted a general practitioner with the same problem.' If such patients are self referred, it is presumed that the general practitioner, having decided that referral to accident and emergency was unnecessary, has already given them appropriate treatment and advice. Consequently such patients often encounter scepticism from accident and emergency staff, when, in reality, little is known about them to justify such an attitude. This study considers the outcome of attendance at accident and emergency departments, comparing self referred patients who have already consulted a general practitioner with other groups.

\section{Methods and results}

For two weeks in November 1988, every tenth adult registering at our accident and emergency department was asked, before seeing a doctor, if they had already consulted a general practitioner with the same clinical problem. After treatment, case notes were examined for routinely coded clinical data, including mode of referral (self, general practitioner, workplace, etc). Cases of unconsciousness, self poisoning, and road accidents were excluded because these groups always require accident and emergency facilities. Also excluded were patients visiting the area or not registered with a local practice and those certified dead on arrival.

From 4560 sequential attenders, 442 cases were identified between 12 and 26 November 1988. Valid responses to the question were obtained from 371 $(84 \%)$.

Of the 371 respondents, 103 had already seen a general practitioner with the same problem before attending. Of these, 67 had been professionally referred, 56 by a general practitioner and 11 by other health care professionals such as a workplace nurse. The remaining 36 patients had referred themselves. Among the 268 patients who had not first seen a genera practitioner, 197 had referred themselves and 71 had been professionally referred.

The table shows the numbers of patients who were discharged, referred to outpatient clinics, or admitted as emergencies. Patients who had already seen a general practitioner before referring themselves to the accident and emergency department $(n=36)$ were jus as likely to be admitted as those in any other group. A total of 24 patients defaulted before completion of treatment (although a working diagnosis had been made by this point), but only one had seen a general practitioner before referring himself to the acciden and emergency department.

\section{Comment}

The tabulated data suggest that considerably more patients than previously recognised $(28 \%)$ attend accident and emergency departments having first seen a general practitioner. ${ }^{\prime}$ In this group $28 \%$ warranted hospital admission. Within this group, patients who had chosen to refer themselves to the accident and emergency department had done so despite having seen a general practitioner who clearly had not recommended such a course of action; none the less these patients were just as likely to require admission (34\%) Scepticism about self referred patients who have

Outcome of consultation in accident and emergency department for 371 attenders

\begin{tabular}{|c|c|c|c|c|c|c|}
\hline & $\begin{array}{c}\text { No refused or did } \\
\text { not wait }\end{array}$ & $\begin{array}{l}\text { No given formal } \\
\text { discharge }\end{array}$ & $\begin{array}{c}\text { No (\%) admitted as } \\
\text { emergency }\end{array}$ & $\begin{array}{l}\text { No given outpatient } \\
\text { appointment }\end{array}$ & Total & \\
\hline Seen by general practitioner & 1 & 46 & $29(28)$ & 27 & & 103 \\
\hline Self referred $(a)$ & 1 & 18 & $12(34)$ & 5 & 36 & \\
\hline Professionally referred (b) & & 28 & $17(25)$ & 22 & 67 & \\
\hline Not seen by general practitioner & 23 & 155 & $31(13)$ & 59 & & 268 \\
\hline Self referred $(c)$ & 18 & 119 & $15(8)$ & 45 & 197 & \\
\hline Professionally referred (d) & 5 & 36 & $16(24)$ & 14 & 71 & \\
\hline
\end{tabular}

Statistics (excluding column 1): whole table, $\chi^{2}=27 \cdot 8, \mathrm{p}=0 \cdot 0001 ;(\mathrm{a}) v(\mathrm{~b}),(\mathrm{a}) v(\mathrm{~d})$ : not significant; (a) $v(\mathrm{c}), \chi^{2}=18 \cdot 1, \mathrm{p}=0 \cdot 0001$. 